\title{
Multicultural \& Diversity: Experience from Muslim Society in Kaohsiung Taiwan
}

\author{
Ardian Bakhtiar Rivai \\ Universitas Ahmad Dahlan, Indonesia \\ ardian.rivai@ppkn.uad.ac.id
}

\begin{abstract}
Abstrat- Taiwan is not the Muslim country, the tolerance from native Taiwan to Muslim migrant in Kaohsiung city could be inspired to other non-Muslim country for multicultural and diversity. Author have fieldwork on eight months at Kaohsiung mosque to interpreted that the interaction from various nations, languages, and culture. There are two important finding that could describes on this study. Firstly, this study interpreted the multicultural and diversity internally of Muslim society in Kaohsiung mosque. Secondly, it is interesting that how native Taiwan respect to the Muslim society in Kaohsiung Mosque. This study recommend that the next research would analyze interaction between Muslim migrant and Taiwan society outside of Kaohsiung Mosque.
\end{abstract}

\section{Keywords: Muslim, Diversity, Taiwan Introduction}

\section{INTRODUCTION}

This paper explores that the international interaction in the Kaohsiung mosque Taiwan. It is interesting to discuss how international interaction could be work on the island which did not have formally international relations. In the mainstream perspective, international interaction among country could be possible if there are some formal diplomatic relations. Study result shows that international interaction among Muslim in Kaohsiung mosque Taiwan reflected the international interaction beyond formally diplomatic relations.

In the difficult situation under domination of mainland China in Taiwan, Muslim society minority however, show the out of the box of international pressing which experienced by Taiwan. Muslim interaction in Kaohsiung Taiwan describes how Taiwan actually has a stable international relation especially in Muslim societies between Taiwanese and other Muslims around the world. Muslim interaction in Kaohsiung actually be different perspective to see how Taiwan is blocked by mainland China was not work properly. Taiwan with all the threats of international and marginalized in all of formal government has a formidable challenge in establishing formal political relations and interactions [1]-[3]. Moreover, multi-culture that took place in Kaohsiung involving many countries around the world became contra productive with international relations theory in mainstream perspective.
This study also proposed the idea that diversity and multicultural approach could be help us to understand international relation differently. Diversity in Taiwan on this paper read by the diversity not only ethnicity in Taiwan, but also diversity in Muslim society internally. Muslim minority organizations might not integrate in Taiwan as host countries [4]. In the same time, the different sect in can also be difficult to integrate in each people.

However, this study finds that Kaohsiung mosque has successfully united various sect, culture, nation, and country in one place which called Kaohsiung mosque.

Seeing diversity in such conditions, providing another explanation of diversity not only creates a harmonious atmosphere among religious people, but also provides another perspective on international relations which is out of the box of mainstream theory. Diversity in Kaohsiung mosque gives a positive impact in building a paradigm about Islam completely. Diversity influence to every other Muslim to respect and tolerance not only with different sect, but also different culture, nation, and religion in Taiwan [5], [6]. In addition, this paper support the idea that melting pot could be apply in Kaohsiung as a model of tolerance among nation [7]. International interaction in Kaohsiung mosque provides a clear picture of the mixing of social interactions giving new nuances about the paradigm and behavior patterns of Muslims in Kaohsiung [8].

\section{KAOHSIUNG MOSQUE: THE SYMBOL of MULTICULTURALISM in TAIWAN}

This study collected the data by get involved directly in Kaohsiung mosque. Author who life in Kaohsiung for eight months always go to Kaohsiung mosque every Friday to observe directly how international interaction does work in this mosque. This study snapshot three model of multiculturalism in Kaohsiung mosque.

First of all, national identity, Kaohsiung mosque became the arena for various national identity to unite in a harmonious social interaction.

Interactions among national identities indicate that social relations are interwoven already ignore different of national identities among them. In this condition, Kaohsiung mosque also can be judge as a Muslim melting pot in 
Taiwan. social interaction with regard to identity differences shows how important multiculturalism is built in such harmonious situations [9], [10].

Secondly, power relations, interactions between Muslims in Kaohsiung show that the relation between majority and minority power relation within the nation. For example, in Kaohsiung mosque we can see that good interaction between sunni and syiah in the middle east can be peacefully in religious tradition. This condition would be difficult to find in the nation where is conflict still work today. The existence of the similarity of fate relationship as settled foreigner gives new experience to them to be able to establish a harmonious interaction between power majority and power minority in Taiwan. However, such conditions confirm that essentially multiculturalism is a concept of recognized the minority cultures by both power majorities and minorities

[9], [11], [12].

Thirdly, the relationship between ideology and practice [13]. This study finds that the different ideology between left Muslim and right Muslim in Indonesia can be harmonic when they are life and interact in Kaohsiung. Conditions like this may be very difficult to find in Indonesia with the diversity of political ideology in the understanding of religions that have different each other. For example, it is difficult in Indonesia to make Hizbut Tahrir Indonesia members and Nahdlatul Ulama members in one forum to discuss about religious perspective on friendly situation. However, we can find this friendly situation in Kaohsiung mosque which accommodate each ideology that totally different in Indonesia.

On the other word, this paper means that multiculturalism will be easier to build in different situations and conditions with different backgrounds. What happens in Kaohsiung mosque shows that conflict between sunni and syiah does not occur when the sect actors live together and side by side in different cultural and religious dimensions with their place of origin. Taiwan as a non-religious region as something recognized by the government provides a new setting place to create new paradigm among Muslims [14], [15]. New setting place impacted to the discourse between different ideology to understand each other about their truth. New settings also offer new thoughts on the different thoughts they have believed [14], [16].

\section{INTEGRATION AMONG MUSLIM CLEAVAGE}

According to the European Parliament's Committee on Civil Liberties, Justice, and Home Affairs on immigrant integration, the definition of integration is that "a society's ability to integrate all its members into new arrangements of active citizenship that ensure the long-term well-being of all in a diverse society" [17]. Amazingly, Kaohsiung mosque as a place of Muslim in Kaohsiung Taiwan to pray, not only to integrating among different sect in Muslim faith, but also among different ideology, identity, and nation of all around the world [14], [18]. It is not difficult that Integrating among different sect of Muslim in their home country [19].
However, what I see in the Kaohsiung mosque could be a model to manage the diversity in Muslim society.

Seeing a collection of friendly discussions among national identity is a very easy routine in Kaohsiung mosque. In fact, the different sect in Syria which was conflict and kill each other just because of them are sunni and syiah was united in Kaohsiung mosque. Interestingly, this integration was not in the Islamic Ritual, but also in the praying activity which is the main core of the reason of debate between sunni and syiah members. What does work in Kaohsiung mosque shows that the confluence of beliefs in one place with the same function and purpose. Kaohsiung mosque was the place that the meeting point of inclusiveness among Muslims. Moreover, inclusion among Muslims is also the manifestation of protection and expression of diversity in Taiwan [14], [17], [20].

In addition, I also saw that the unique relation between different Muslim ideology from Indonesia. How to associate between left and right ideology in Indonesia can be integrated in Kaohsiung. It is interesting to see that members of Nahdlatul Ulama and

Hisbut Tahrir Indonesia are integrated in the same community of the Ikatan Warga Muslim Indonesia di Taiwan (association of Indonesian Muslim in Taiwan). Forum Mahasiswa Muslim Indonesia di Taiwan (Indonesian Muslim student forum) is also represented the integration of Muslim student from different ideology which is actually not integrated in Indonesia. In Kaohsiung, they were integrated and have good relationship in the weekly activity which they called as "Liqo". They also have some activity which is developing the multiculturalism by the integrated different ethnic in Indonesia.

However, the leader of Kaohsiung mosque who is a native Taiwanese also effected the social integration in Kaohsiung. Muslim integration in Kaohsiung mosque is the result of social setting that forces Muslims from around the world to adhere to the integration mechanism by the leader of mosque. This mechanism provided by indirect effect of religious ritual is not realized. All of Muslim in this mosque is regulated unconsciously by the condition that imam mosque having different national identity gives effect that there is multicultural condition which consciously considered as pluralistic conception of social norms [21]. This condition must be maintained to provide tolerant thinking with different national identity and religious sect. I also argue that a leader of Kaohsiung has an awareness for unity in the assimilation framework.

Taiwanese as an indigenous identity in Kaohsiung also contributed to decrease of discrimination and racism which is possible if the leader of mosque nonTaiwanese as indigenous identity [22]. This presumption developed by the logic that more racism which was happen in Muslim country is just because of they do not accept with the different sect or sometime different race. Maintaining conditions in situations as foreign citizens is very important in understanding the diversity of Muslims in Kaohsiung. There is a tendency that Muslims are relatively more tolerant if they belief that they are minority compare with the situations which they are majority. In consequence, the 
mindset of Muslim minority also effected to settle the behavior of interaction of the other in the minimize of "affective inequality" [23].

\section{CONCLUSION: BEYOND INTERNATINAL RECOGNITION of TAIWAN}

In this case, the diversity among nation in Kaohsiung mosque interpreted as a beyond of international recognition. Muslim integration which accommodate Muslim from country around the world was another term of international recognition of Taiwan as national identity. Taiwanese people who lead the mosque and social interaction among multiculturalism also as a unique pattern that represent of the term of recognition [24]-[26]. On the other hand, I also argue that the unify of Muslim which representing different national identity could be the symbolize of conception of Muslim country recognition. We also can see that there are so many flag which was show on the wall of the Kaohsiung mosque. Islam as a minority religion in Taiwan contributed to develop what we called as "great power" recognition which is in Taiwan case was vital in key of international politics [27].

\section{ACKNOWLEDGMENT}

I would like to thank Beasiswa Unggulan Dosen Indonesia Lembaga Pengelola Dana Pendidikan (BUDI LPDP) Ministry of Research,

Technology, and Higher Education; and Ministry of Finance; Republik Indonesia that sponsored my Ph.D program in Institute of Political Science, National Sun Yat Sen University, Taiwan.

\section{REFERENCES}

[1] J. C. Hsiung, "The ROC's (Taiwan's) Quest for Wider International Participation*," Am. Foreign Policy Interes., vol. 28, no. 3, pp. 255-268, 2006.

[2] F. C. Liu and Y. Li, "Generation matters: Taiwan's perceptions of mainland China and attitudes towards cross-strait trade talks," J. Contemp. China, vol. 26, no. 104, pp. 263-279, 2017.

[3] F. C. Liu, "Taiwanese Voters 'Political Identification Profile, Becoming One China or Creating a New Country?," vol. 56, no. 5, pp. 931-957, 2014.

[4] I. Kalin, "Religion, unity and diversity," Philos. Soc. Crit., vol. 37, no. 4, pp. 471-478, 2011

[5] S. Choi, "Diversity in the U.S. Federal Government: Antecedents and Correlates of Diversity in Federal Agencies," Rev. Public Pers. Adm., vol. 30, pp. 301-321, 2010.

[6] K. Soldatic, "What we have done," Disabil. Soc., vol. 27, no. 6, pp. 895-897, 2012.

[7] T. Gales, "'Diversity' as enacted in US immigration politics and law: a corpusbased approach," Discourse Soc., vol. 20, no. 2, pp. 223-240, 2009.

[8] K. Soldatic, "The transnational sphere of justice: disability praxis and the politics of impairment," Disabil. Soc., vol. 28, no. 6, pp. 744-755, 2013.

[9] W. D. Bokhorst-Heng, "Multiculturalism's narratives in Singapore and Canada: Exploring a model for comparative multiculturalism and multicultural education," J. Curric. Stud., vol. 39, no. 6, pp. 629-658, 2007.

[10] K. Soldatic, "Postcolonial reproductions : disability , indigeneity and the formation of the white masculine settler state of Australia," Soc. Identities, vol. 21, no. 1, pp. 53-68, 2015.

[11] K. Nagayoshi, "Support of Multiculturalism,

But For Whom? Effects of Ethno-National Identity on the Endorsement of Multiculturalism in Japan," J. Ethn. Migr. Stud., vol. 37, no. 4, pp. 561-578, 2011.

[12] K. Soldatic and A. Chapman, "Surviving the assault? the Australian disability movement and the neoliberal workfare state," Soc. Mov. Stud., vol. 9, no. 2, pp. 139-154, 2010.

[13] N. Kandasamy and K. Soldatic,

"Implications for Practice: Exploring the Impacts of Government Contracts on Refugee Settlement Services in Rural and Urban Australia," Aust. Soc. Work, vol. 0, no. 0, pp. 1-9, 2017.

[14] D. W. V. A. Samararatne and K. Soldatic,

"Inclusions and exclusions in law: experiences of women with disability in rural and war-affected areas in Sri Lanka," Disabil. Soc., vol. 30, no. 5, pp. 759-772, 2015.

[15] S. Grech and K. Soldatic, "Disability and colonialism: (dis)encounters and anxious intersectionalities," Soc. Identities, vol. 21, no. 1, pp. 1-5, 2015.

[16] C. Grover and K. Soldatic, "Neoliberal restructuring, disabled people and social (in)security in Australia and Britain," Scand. J. Disabil. Res., vol. 15, no. 3, pp. 216-232, 2013.

[17] P. I. Jackson, "Measuring Muslim Integration in Europe," Democr. Secur., vol.

5, no. 3, pp. 223-248, 2009.

[18] N. Kandasamy, K. Soldatic, and D.

Samararatne, "Peace, justice and disabled women's advocacy: Tamil women with disabilities in rural post-conflict Sri Lanka," Med. Confl. Surviv., vol. 3699, no. October, pp. 1-19, 2017.

[19] M. Wojcieszak, R. Azrout, H.

Boomgaarden, A. P. Alencar, and P.

Sheets, "Integrating muslim immigrant minorities: the effects of narrative and statistical messages," Communic. Res., vol. 44 no. 4, pp. 582-607, 2017.

[20] A. C. Ciciora, "Integrating ireland's muslims: Attitudes of muslim and irish elites towards value compatibility and the mainstreaming of Islam," J. Muslim Minor. Aff., vol. 30, no. 2, pp. 199-216, 2010.

[21] R. van Krieken, "Between assimilation and multiculturalism: models of integration in Australia," Patterns Prejudice, vol. 46, no. 5, pp. 500-517, 2012.

[22] K. Spurway and K. Soldatic, “'Life just keeps throwing lemons': the lived experience of food insecurity among Aboriginal people with disabilities in the West Kimberley," Local Environ., vol. 21, no. 9, pp. 1118-1131, 2016.

[23] K. Soldatic and H. Meekosha, "Moving the Boundaries of Feminist Social Work

Education with Disabled People in the Neoliberal Era," Soc. Work Educ., vol. 31, no. 2, pp. 246-252, 2012.

[24] H. Agné et al., "Symposium 'The politics of international recognition,"' Int. Theory, vol. 5, no. 1, pp. 94-107, 2013.

[25] B. Ong, "Recognizing regions: ASEAN's struggle for recognition," Pacific Rev., vol. 25, no. 4, pp. 513536, 2012.

[26] R. Wolf, "Respect and disrespect in international politics: the significance of status recognition," Int. Theory, vol. 3, no. 1, pp. 105-142, 2011.

[27] N. Mirilovic and D. S. Siroky, "International Recognition and Religion : A Quantitative Analysis of Kosovo 's Contested Status International Recognition and Religion: A Quantitative Analysis of Kosovo 's Contested Status," Int. Interact., vol. 43, no. 4, pp. 668-687, 2017. 